\title{
Factors Influencing the Choice of Investment in Life Insurance Policy
}

\author{
Ravi Kumar Tati, Ernest Beryl B. Baltazar \\ European International College, Abu Dhabi, UAE \\ Email: raviktati@gmail.com, ebbbaltz@gmail.com
}

How to cite this paper: Tati, R.K. and Baltazar, E.B.B. (2018) Factors Influencing the Choice of Investment in Life Insurance Policy. Theoretical Economics Letters, 8, 3664-3675.

https://doi.org/10.4236/tel.2018.815224

Received: October 15, 2018

Accepted: December 24, 2018

Published: December 27, 2018

Copyright $\odot 2018$ by authors and Scientific Research Publishing Inc. This work is licensed under the Creative Commons Attribution International License (CC BY 4.0).

http://creativecommons.org/licenses/by/4.0/

\begin{abstract}
Insurance industry in India is flourishing with numbers of national and global players in the form of joint ventures and is excelling with the exponential growth in business. In spite of infusing several rules and regulations of the Government of India, insurance industry has been experiencing tremendous progress in terms of increasing number of investors with considerable number of new entry of insurance companies into the sector. At present there are 24 numbers of domestic and foreign players operating in the sector. In India insurance still has been considered as a tax saving tool rather than an investment option. The present study analyzes the Factors Influencing the Choice of Investors in Life Insurance Policy in Hyderabad city. The specific objective was to find out whether there is any association between annual income of investor and factors influencing consumer choice of investment in life insurance. A sample of 75 insurance investors' data was statistically analyzed with the help of Chi-square test and the study was concluded that there is no association between annual income and factors influencing investor choice of investment in life insurance. It is suggested that the majority of the investors' should treat insurance policy is not only a tax saving option but also the risk protection and a multi-faceted investment option. The author also acknowledges the limitation of the small sample which may not be exhaustive for any policy decision of the insurance companies. Hence, the findings of the study are to be correlated with the current trends in the industry with a comprehensive study.
\end{abstract}

\section{Keywords}

Insurance, Investor, Tax Benefits, Risk Protection, Multi-Faceted Investment Option

\section{Introduction}

Insurance is one of the important options for the investors for yielding 
long-term returns, tax benefits as well as risk coverage. The human life is exposed to constant. At the same time, being individual, he has the responsibilities to discharge. Indian consumers are highly influenced by emotional factors. But at the same time their investment behaviour in insurance policy is influenced by rational factors. A Typical Indian believes in future and tries to have better and self secured life for his family. A rupee earned by the person will be spent towards leading the family in present and for the better life in future. Exactly here life insurance companies are trying to cover the components viz., saving, risk coverage and investment as well. As the economy comprises of middle classed and salaried, insurance is emerging as the best option for long-term saving and risk coverage. In India, insurance is still a well thought-out as a tax saving tool instead of its additional implied long term financial benefits. Generally most Indians prefer to invest in acquiring property and gold followed by bank deposits, but they do not consider insurance policy as an investment. They selectively invest in shares also but the percentage is extremely small [1].

\section{Why Investment in Life Insurance Policy?}

We are living in the era of uncertainty in every spear of life. Yet the average Indian does not consider it as a serious decision which he cannot afford to neglect. A meagre 10 percent of the Indian population purchase insurance products in India. Though there is enough disposable income to subscribe for the insurance policies, this is a least priority for majority of the individuals. Hence, there is a long-time argument that insurance habits are to be imposed upon rather than making it optional. This not only secures the life of the insured, but imparts financial discipline and saving habits resulting in corpus. Funds mobilised through insurance policies may be channelled to the capital needed for the productive needs of the economy. Saving helps in propelling the growth of the industry and domestic production. Today, across the world and in India in particular, the insurance companies have been called as the institutional investors who move the stock market indices. The health of the economy is demonstrated through the performance of the capital markets. That is why the stock exchanges are referred to as the barometers of the economy. There are some misconceptions about the insurance products. These myths have to be cleared to accelerate the growth of the insurance business in India. According to Sandeep Chaudhary [2], the needs for life insurance are to: 1) meet family's financial requirements in future; 2) clear outstanding loans and expenses; 3 ) diversify investment options; 4) avail tax benefits; 5) avail loans against Insurance policy documents. However, the underlying factors which are influencing the investment decision of an investor include: 1) security \& assurance; 2) The debt issue; 3) retirement plans; 4) long term plans \& dreams; 5) tax benefits; 6) risk coverage \& savings; and 7) family welfare, etc.

\section{Literature Review}

Babita Yadav \& Anshuja Tiwari [3] made an attempt to identify those factors 
which influence customers policy buying decision and also analyze the preferences of customers while life policy investment decision-making in Jabalpur district, of Madhya Pradesh. The LIC is the most accepted and popular brand in life insurance, the industry share of private insurers are gradually increasing with people trust and better services offered by them are some of the main findings of the study. Antony Beckett, Paul Hewer and Barry Howcraft [4] found that new technology has created highly competitive market conditions which have huge impact on consumer behavior in financial services. The researchers have stressed that the service providers need to understand the buying behavior of customers. A model was proposed to understand the concept of consumer behaviour towards financial products. Kyoko Fukakawa [5] based on the data collected form 72 UK customers explored the possible occurrence ethically questionable consumer behavior. Sandeep Chaudary [2] has extracted six factors that influencing investor behavior includes customized and timely services, better company reputation, customer convenience, better service quality, tangible benefits and effective customer relationship management.

Narender and Sampath [6] have stated that though insurance industry is old, the awareness on rules, regulations and rights is very negligible. Through the empirical study conducted among the respondents, it was concluded that major financial need for the customer in the near future will be children's education and marriage expenses. Dipin Mathur and Ashish Tripathi [7] have studied 29 factors that influence choice of customer in choosing an insurance company in Ajmer city. From the study, it was found that there are 9 key factors among 29 which contain clubbing variables that highly influencing the choice of customers in choosing insurance companies. Vijaya Raghunadhan [8], in his study on consumer behaviour towards life insurance companies with reference to two private insurance companies revealed that consumer behavior and customer purchase service attempts are depends on factors like Search, experience and credence factors. The study concluded that customers will give preference to wealth insurance schemes. Praveen Kumar Tripathi [9], in his study "customer buying behavior with a focus on market segmentation" examined buying pattern in the insurance industry with a special focus on HDFC standard life insurance. The markets are divided in terms of insurance needs, age groups, satisfaction levels etc were taken into account to know the customer perception and expectation from private insurers.

Sidhardha \& Sumanth [1] have analyzed the factors that influencing a typical customer in choosing a particular insurance company when he needs an insurance policy in Visakhapatnam city. Mahajan [10] conducted a study on consumer decision making process in life insurance services and found that there are 5 stages i.e. need recognition, search of alternative, evaluation of alternative, purchase decision and post purchase evaluation. Special considerations pertaining to insurance industry are perceived risk, risk and standardisation and risk and information. She even formulated certain stages to improve customer awareness about benefits of life insurance products like focusing on marketing 
techniques. Thus she concluded that the consumer's perception towards Life Insurance policies is positive. There is a positive mindset developed for the investment pattern, in insurance policies. Still concrete actions are needed in the insurance market for a sustainable growth. Rajavardhan and Jahangir (2015), study found that the socio demographic and economic variables that have impact on decision of consumer perception in Nalgonda district. They found that gender and marital status people residing in urban areas invest more in LIC.

\section{Research Gap}

There are plethora of studies conducted in the area of insurance industry, and the factors which influence the decisional pattern of the policy holders. But no study has identified the insurance as investment and saving tool in in the city of Hyderabad of southern India. Hence a modesty attempt has been made with a small sample of 75 respondents in the present study. This study could be a catalyst for the deeper and exhaustive studies in south India where the per capita and disposable income levels are high when compared to the north India.

\section{Need for the Study}

A Large number of new players have entered the market and are trying to expand market share in this swiftly improving marketplace. The current Insurance Industry in India has seen a remarkable expansion by leveraging LPG (Liberalization, privatization, Globalization) initiative. It has endured a major face-lift and surfaces with conspicuous developments. At this juncture, this study aims in identifying the demographic profile of investors; the factors influencing the choice of investors in choosing a life insurance policy as an investment; and to explore the choice of insurance company for investment. Even today many people are considering insurance as a saving option, in the minds of investors about the insurance policies and different insurance companies. But it has to be considered as a long-term investment with multiple benefits and with this view this study was undertaken.

\section{Objectives of the Study}

The objectives of the study are:

1) To present the demographic profile of investors in life insurance policy;

2) To study the factors influencing the choice of investors in choosing a life insurance policy as an investment;

3) To find out whether there is any association between annual income and factors influencing investors' choice of investment in life insurance; and

4) To explore the choice of insurance company for investment.

\section{Hypothesis}

There is no association between the annual income of the investors and factors influencing the choice of investment in life insurance. 


\section{Methodology and Scope}

In this study both primary and secondary sources of data have been used. The primary data was collected through a self administered questionnaire that contained questions relating to the objectives of the study. The questionnaire contains certain question regarding awareness level and the attributes that investors consider while buying a life insurance policy. The Chi-square test has been employed to find out there is any association between annual income and factors influencing investor choice of investment in life insurance. The scope of the study include; 1) the demographic profiles of respondents, 2) Monthly investments in insurance; 3) factors consider while choosing an insurance policy*; 4) awareness on Insure companies and policy details; 5) duration of the policy and the target; 6) sources of buying Insurance policy and premium payment methods; and choice of Insurance Company. This study is confined only to the insurance customers' perceptions in the city of Hyderabad. A sample of 75 insurance investors was considered for the study from a huge population of various policy holders of life Insurance, the sample covers both LIC and Private insurance companies but not covered extensively.

\begin{tabular}{cc}
\hline Factors influencing the choice & Security \& Assurance \\
of investors in choosing a life insurance policy* & Tax Benefit \\
& Risk coverage \& Savings \\
Product features & Other factors \\
\hline
\end{tabular}

\section{Analysis and Interpretation}

In this section, an attempt has been made to analyze (1) the demographic profiles of respondents and other factors included in the study. From Table 1, it was revealed that there are 35 percent of respondents are graduates and 20 percent of them are post-graduates. Regarding profession, majority of the respondents are employees whose percentage is 36 followed by business with 15 percent. Majority of the respondents are in the age group between 30 and 50 years with a percentage of 43 followed by another age group above 50 years with 33 percent. In terms of the income of the respondents, 24 percent of the policy holders are with an income levels of Rs. 9,000,000 or above while 23 percent are with an income level between Rs. 900,000 and 600,000. A 21 percent of the respondents holds income level between Rs. 600,000 and 300,000. Among them, 79 percent of the respondents are male while 21 percent are female policy holders. From this analysis, it can be inferred that the majority of respondents are well qualified, employed, relatively good earners showing interest in taking insurance policy as an investment.

Monthly investment in insurance: Table 2 shows that majority numbers of respondents (36\%) have been investing less than 10 percent, 25 percent of them investing between $10 \%-15 \%, 22$ percent are investing between $21 \%-25 \%$ 
Table 1. Demographic profile of respondents $(\mathrm{N}=75)$.

\begin{tabular}{|c|c|c|}
\hline \multicolumn{2}{|c|}{ Demographic factors } & \multirow{2}{*}{$\begin{array}{c}\text { Responses } \\
06\end{array}$} \\
\hline \multirow{4}{*}{ Education Level } & Up to SSC & \\
\hline & Graduates & 35 \\
\hline & Post Graduates & 20 \\
\hline & Others & 14 \\
\hline \multirow{4}{*}{ Occupation } & Business & 15 \\
\hline & Employed & 36 \\
\hline & Self-employed & 13 \\
\hline & Others & 11 \\
\hline \multirow{3}{*}{ Age (Yrs) } & Below 30 & 24 \\
\hline & $30-50$ & 43 \\
\hline & Above 50 & 33 \\
\hline \multirow{4}{*}{ Annual Income (Rs) } & $<3,00,000$ & 07 \\
\hline & $3,00,000-6,00,000$ & 21 \\
\hline & $6,00,000-9,00,000$ & 23 \\
\hline & $>9,00,000$ & 24 \\
\hline \multirow{3}{*}{ Gender } & Male & $79 \%$ \\
\hline & Female & $21 \%$ \\
\hline & Total & 100 \\
\hline
\end{tabular}

Source: Field data.

Table 2. Monthly investments in insurance.

\begin{tabular}{ccc}
\hline Monthly investment (\%) & Frequency & Percentage (\%) \\
\hline Below 10\% & 27 & 36 \\
$10 \%-15 \%$ & 19 & 25 \\
$16 \%-20 \%$ & 16 & 22 \\
$21 \%-25 \%$ & 09 & 12 \\
Above 26\% & 04 & 05 \\
Total & 75 & 100
\end{tabular}

Source: Field data.

and rest of them are investing more than $21 \%$ from their income. This means majority of the respondents are aware of the benefits of long term investment in insurance policy.

Factors influencing the choice of the policy holder: While considering the factors influencing buying decisions of an insurance policy, majority of the respondents (28\%) are influenced by its Tax benefits, followed by 21 percent of them against Risk coverage \& savings, Security \& Assurance with 20 percent. It 
is also found that there are 16 of respondents considering the product features as the factor influencing them to invest in Insurance policy. Other factors (16\%) include the Debt Issue (4\%), Retirement plans (4\%), Long Term Plans \& Dreams (4\%) and family welfare (3\%). It can be inferred that tax benefits, security \& assurance and the product features are most influential factors for choosing insurance as an investment avenue besides other factors (Table 3 ).

To find out whether there is any association between annual income and factors influencing investor choice of investment in life insurance.

$\mathrm{H}_{0}$ : There is no significant association between Annual Income and factors influencing the choice of investment in life insurance.

\begin{tabular}{|c|c|c|c|c|c|c|}
\hline \multirow[b]{2}{*}{ Annual Income (Rs.) } & \multicolumn{5}{|c|}{ Factors Influencing Choice of Investment in Insurance } & \multirow[b]{2}{*}{ Total } \\
\hline & $\begin{array}{l}\text { Security \& } \\
\text { Assurance }\end{array}$ & $\begin{array}{c}\text { Tax } \\
\text { Benefit }\end{array}$ & $\begin{array}{l}\text { Risk coverage } \\
\text { \& Savings }\end{array}$ & $\begin{array}{l}\text { Product } \\
\text { features }\end{array}$ & $\begin{array}{l}\text { Other } \\
\text { factors }\end{array}$ & \\
\hline$<300,000$ & 0 & 2 & 3 & 1 & 1 & 07 \\
\hline $300,000-600,000$ & 3 & 4 & 4 & 5 & 5 & 21 \\
\hline $600,000-900,000$ & 4 & 5 & 5 & 4 & 5 & 23 \\
\hline$>900,000$ & 8 & 10 & 4 & 2 & 0 & 24 \\
\hline Total & 15 & 21 & 16 & 12 & 11 & 75 \\
\hline $\begin{array}{c}\text { Chi Square } \\
\text { Calculated Value) }\end{array}$ & \multicolumn{6}{|c|}{6.321} \\
\hline Degree of freedom & \multicolumn{6}{|c|}{5} \\
\hline Tabulated Value & \multicolumn{6}{|c|}{12.592} \\
\hline Accept/Reject & \multicolumn{6}{|c|}{ Accept } \\
\hline
\end{tabular}

Result: Since the calculated value of Chi-square (6.321) is less than the tabulated value (12.592), the null hypothesis is accepted. Hence, it is concluded that there is no significant relationship between annual income of the investors and the factors influencing choice of investment in life insurance.

Awareness about Insurance: The education and awareness towards the fraudulent activities is also a factor which influences the policy holders to know the policy details before they choose and buy. Table 4 shows the number of respondent knows insurance policy and awareness details of the policy before they

Table 3. Factors influencing the choice of the policy holder.

\begin{tabular}{ccc}
\hline Factors & Frequency & Percentage (\%) \\
\hline Security \& Assurance & 15 & 20 \\
Tax Benefit & 21 & 28 \\
Risk coverage \& Savings & 16 & 21 \\
Product features & 12 & 16 \\
Other factors & 11 & 15 \\
TOTAL & 75 & 100
\end{tabular}

Source: Field data. 
Table 4. Awareness on Insurance companies and policy details.

\begin{tabular}{cccc}
\hline & No. Of Companies & Frequency & Percentage (\%) \\
\cline { 2 - 4 } & $1-3$ & 35 & 47 \\
Awareness of & $4-5$ & 19 & 26 \\
Insurance companies & $5-10$ & 12 & 16 \\
& $>10$ & 08 & 11 \\
& Total & 75 & 100 \\
\hline Awareness on Policy & Yes & 59 & 79 \\
details before investment & No & 16 & 21 \\
& Total & 75 & 100 \\
\hline
\end{tabular}

Source: Field data.

buy. Majority of the respondents' (41\%) have known only one to three companies. 26 percent of them could know 4 - 5 insurance companies and rest of them aware of more companies in the sector. However, one of them being Life insurance Corporation of India and only 11 percent of the respondents know more than 10 insurance companies. The results shows that majority of the policyholders are unaware of different insurance companies. If we understand the policy awareness levels, 79 percent of them are aware of details about the policy before they invest in the form of life insurance policy.

Duration of the policy and the target investment: Table 5 shows 35 percent of the respondents are like to invest for a period of more than 10 years but less than 15 years, 32 percent of the respondents like to invest for a period of 15 to 20 years, $16 \%$ of the respondents like to invest for a period of less than 10 years, $17 \%$ of the respondents like to invest for a period of more than 20 years. This shows that the large number of customers prefer to invest for longer periods say 10 years and more. At the same time majority of the respondents will buy the insurance policy for their own self (44\%) and next preference will be given for spouse (21\%) followed by children (20\%) and only 15 percent is for covering parents. This reveals a fact that most of the policy holders bought the policies in order to cover the risk and avail the tax benefits from the government.

Sources of buying Insurance policy and premium payment methods: Table 6 shows the preferable source of investment. It is interesting to note that while $35 \%$ of the respondents now buying insurance policy directly from the insurance companies, 32 percent of them could buy insurance policy through Insurance advisors or agents of the company where as $16 \%$ of them could buy from the banks. Further, it is also found that there are $21 \%$ of respondents are able to buy from other sources such as external brokers. Similarly, if we analyze premium payment options of the respondents, majority of the respondents prefer to pay the monthly premium (52\%), whereas 22 percent likes pay quarterly and half yearly it was about 11 percent and 15 percent of them prefers to pay annually. The study concludes that majority of the respondents opt to pay monthly and quarterly premium. 
Table 5. Duration of the policy and the target investment.

\begin{tabular}{cccc}
\hline & Duration & Frequency & Percentage (\%) \\
\cline { 2 - 4 } Duration of the policy & $<10$ Yrs & 12 & 16 \\
& $10-15$ Yrs & 26 & 35 \\
& $15-20$ Yrs & 24 & 32 \\
& $>20$ Yrs & 13 & 17 \\
& Total & 75 & 100 \\
\hline \multirow{3}{*}{ For whom policy is purchased } & Target & Frequency & Percentage (\%) \\
\cline { 2 - 4 } & Self & 33 & 44 \\
& Spouse & 16 & 21 \\
& Children & 15 & 20 \\
& Parents & 11 & 15 \\
& Total & 75 & 100 \\
\hline
\end{tabular}

Source: Field data.

Table 6. Source of buying Insurance policy and premium payment methods.

\begin{tabular}{cccc}
\hline & Source & Frequency & Percentage (\%) \\
\cline { 2 - 4 } $\begin{array}{c}\text { Source for buying } \\
\text { the Insurance Policy }\end{array}$ & Advisors/Agents & 24 & 32 \\
Insurance Companies & 23 & 35 \\
& Banks & 12 & 16 \\
Others & 16 & 21 \\
Total & 75 & 100 \\
\hline Mode of payment & Frequency & Percentage (\%) \\
\cline { 2 - 4 } Premium & Monthly & 39 & 52 \\
Qayment methods & Quarterly & 17 & 22 \\
& Half yearly & 08 & 11 \\
& Annually & 11 & 15 \\
& Total & 75 & 100
\end{tabular}

Source: Field data.

Choice of Insurance Company: Table 7 presents the choice of insurance company and the majority of the respondents prefer to invest still in LIC since it's a public sector organization. The study shows that $58 \%$ of the respondents prefer to invest in LIC of India whereas only $42 \%$ of the respondents prefer to choose insurance policy from the private insurance companies i.e., other than LIC of India. The reason could be it's a public sector organization and feeling of safe investment. 
Table 7. Choice of insurance company.

\begin{tabular}{ccc}
\hline Company & Frequency & Percentage (\%) \\
\hline LIC of India & 44 & 58 \\
Private Insurance companies & 31 & 42 \\
Total & 75 & 100 \\
\hline
\end{tabular}

Source: Field Data.

\section{Major Findings}

1) The study on factors influencing the choice of investors in life insurance policy as an investment avenue and has revealed several facts. It was found that majority of the investors in life insurance are male (79\%) in number when compared with females. The age group which prefers to invest more in Insurance are below 40 years age group. As per the educational background, the Post graduates and graduates are showing more interest in taking insurance policies as they have more awareness levels.

2) As salaried policy holders are showing interest in saving, majority of the respondents prefer to save $10 \%$ to $20 \%$ of their disposable income in the form of insurance policy. It is found that majority of the people like to invest in both short term policies than long term policies. It was also found that family, advisors and self-interest are major drivers in investing in insurance.

3) The tax benefits, risk coverage and savings are the major factors influencing the investors to choose insurance policy. It was also found that majority of the respondents know up to 3 insurance companies only and LIC is being one among them. It is very interesting to note that the investors prefer to buy insurance policy directly from the insurance companies for himself/herself and spouse.

4) It was also found that LIC still playing major role with huge number of investors and prefers to take Insurance policy form Public sector insurance companies than private sector insurance companies. The periodicity of investment lies from 5 years to 20 years basing on the duration of the policy.

5) It was found that an investor of life insurance they prefer to pay monthly premium and quarterly. The study presents an interesting fact that majority of the customers have awareness on details of the policy they buy. Finally, the study on factors influencing the choice of investors in life insurance policy as an investment in Hyderabad city has revealed the facts that are influencing a typical Indian insurance investor to take an Insurance policy.

\section{Suggestions}

1) The number of female employees is growing as earners which have to be captured by these insurance companies in its fold as potential investors by designing suitable policies and marketing strategies. In present competitive world, customer satisfaction and grievances handling procedures should be revisited which has become now an important aspect to retain the investors, not only to 
grow and survive. Investor service is the critical success factor and private insurers through their best services would be able to reposition and differentiate itself from LIC.

2) The insurance companies should introduce new and innovative products and friendly Investor services will certainly enhance better Investor relationship management (IRM).

3) Children plans by these insurance companies should be introduced and help them to utilize for their higher studies which has become expensive now a days. In this direction, Private insurers should emphasis more on advertising and building brand awareness through different modes of communication. This will help in spreading insurance awareness among the common man.

4) To achieve greater insurance penetration, the healthier competition has to be intensified by both public and private sector companies and they should come up with lower premium and new innovative products to offer greater variety or choice to the investors and also make improvement in the quality of services and sell products through appropriate distribution channel to win-win situation for both the parties i.e., investors and insurance companies.

5) Insurance companies should devise policies which provide effective risk coverage rather than focusing on the tax benefits and also encourages them for long term investment in insurance. Furthermore, Life insurance companies should come up with innovative tailor-made products with high risk cover, more return and low insurance premium to attract more number of investors.

\section{Conclusion}

India is a developing country where income levels of the people are increasing with increased opportunities. As a result their disposable incomes are also increasing which paves a path for insurance companies to gather and explore the opportunities. According to this study, the overall perception of investors towards life insurance is found to be positive. If the private insurance companies try to provide and serve the investors with service quality coupled with empathy and assurance, India could become a biggest market for any insurance company. This study was focused to identify the underlying reasons, facts that influence the investors to invest in life insurance. Majority of the customers feel insurance as a tax saving option than the risk protection and should be a multi-faceted investment option. If their investment patterns are analyzed, majority of the investors prefers long term investments options. The study concluded that there is no association between annual income of investors and factors influencing choice of investment in life insurance. The major influencing factors in choosing an insurance company in the future are supposed to be investor relationships, company image and at lower premium.

\section{Acknowledgements}

Thanks all the authors for their contribution on the subject in their studies as literature review. Their contributions became basis for this paper. 


\section{Conflicts of Interest}

The author declares no conflicts of interest regarding the publication of this paper.

\section{References}

[1] Sidhardha, D. and Sumanth, M. (2017) Consumer Buying Behaviour towards Life Insurance: An Analytical Study. International Journal of Commerce and Management Research, 3, 1-5.

[2] Chaudhary, S. (2016) Consumer Perception Regarding Life Insurance Policies: A Factor Analytical Approach. Pacific Business Review International, 9, 52-61.

[3] Yadav, B. and Tiwari, A. (2012) A Study on Factors Affecting Customers Investment towards Life Insurance Policies. International Journal of Marketing, Financial Services \& Management Research, 1, 106-123.

[4] Beckett, A., Hewer, P. and Howcroft, B. (2000) An Exposition of Consumer Behaviour in the Financial Services Industry. International Journal of Bank Marketing, 18, 15-26. https://doi.org/10.1108/02652320010315325

[5] Fukukawa, K. (2002) Developing a Framework for Ethically Questionable Behavior in Consumption. Journal of Business Ethics, 41, 99-119. https://doi.org/10.1023/A:1021354323586

[6] Narender, S. and Sampath, L. (2014) Consumer Awareness towards Life Insurance Sector in India. Abhinav International Referred Journal of Research in Management and Technology, 3, 45-51.

[7] Mathur, D. and Tripathi, A. (2014) Factors Influencing Customer's Choice for Insurance Companies-A Study of Ajmer City. IOSR Journal of Business and Management, 16, 35-43.

[8] Vijaya Ragunathan, M. (2016) Consumer Behaviour towards Life Insurance Products with Reference to IDBI Fortis Company Limited, Dindigul District. International Journal of Applied Science, 6, No. 8.

[9] Tripathi, P.K. (2008) Customer Buying Behaviour with a Focus on Market Segmentation, Summer Training Project, Chandigarh Business School Mohali, 42-46.

[10] Mahajan, K. (2013) Analysing Consumer Decision Making Process in Life Insurance Services. International Journal of Marketing, Financial Services \& Management Research, 2, 60-68. 